\title{
Anxiolytic-like effects of nociceptin/orphanin FQ in the elevated plus maze and in the conditioned defensive burying test in rats
}

\author{
Giovanni Vitale ${ }^{a, *}$, Rossana Arletti $^{a}$, Valentina Ruggieri $^{a}$, Carlo Cifani $^{b}$, \\ Maurizio Massi ${ }^{b}$ \\ ${ }^{a}$ Department of Biomedical Sciences, Section of Pharmacology, University of Modena and Reggio Emilia, I-41100 Modena, Italy \\ ${ }^{\mathrm{b}}$ Department of Pharmacological Sciences and Experimental Medicine, University of Camerino, I-62032 Camerino, Italy
}

\section{A R T I C L E I N F O}

Article history:

Received 2 March 2006

Received in revised form

3 April 2006

Accepted 4 April 2006

Published on line 26 May 2006

Keywords:

Nociceptin/orphanin FQ (N/OFQ)

UFP-101

NOP receptor

Anxiety tests

Corticosterone

Rat

\begin{abstract}
A B S T R A C T
Different reports suggest that nociceptin/orphanin FQ (N/OFQ) may have either anxiolyticor anxiogenic-like effect in rodents. Since N/OFQ elicits hypolocomotion, which undergoes rapid tolerance, and hypolocomotion may be associated to emotional consequences, the present study was designed to investigate the effect of N/OFQ on anxiety after development of tolerance to its hypolocomotor effect. The effect of single or double intracerebroventricular (i.c.v.) injection of N/OFQ was evaluated on anxiety-related behaviors in rats, in the elevated plus maze (EPM) and conditioned defensive burying (CDB) tests. After single administration, N/OFQ displayed an anxiogenic-like pattern of response on the elevated plus maze but hypolocomotion was also observed. Conversely, in the CDB test, N/OFQ induced a clear-cut anxiolytic pattern. To produce tolerance to N/OFQ-induced hypolocomotion the peptide was administered by two i.c.v. injections separated by $120 \mathrm{~min}$; in these conditions it decreased the expression of anxiety-related behaviors in both tests without affecting locomotor activity. The nociceptin/orphanin FQ peptide (NOP) receptor antagonist UFP-101 significantly reduced the effects of N/OFQ to control values in either tests. Corticosterone levels were significantly increased after a single N/OFQ administration (not in a dose-dependent manner) but this increase did not reach significance after double administration ( $1 \mathrm{nmol} / \mathrm{rat}$ ). Our results support the idea that N/OFQ may act as an anxiolytic-like agent in the rat; the apparent anxiogenic-like effect observed following its single administration in the EPM may be consequent to its effect on locomotion.
\end{abstract}

(C) 2006 Elsevier Inc. All rights reserved.

\section{Introduction}

First identified in 1995, the 17-amino acid peptide nociceptin/ orphanin FQ (N/OFQ) is the endogeous ligand for the "orphan" opioid receptor ORL-1 (now NOP) [32,45]. N/OFQ is quite selective for NOP receptor, while showing no appreciable affinity for $\mu$ opioid (MOP), $\delta$ opioid (DOP) or $\kappa$ opioid (KOP) receptors $[34,51,53,24,31]$. Nevertheless, studies on the cellular effects and the underlying transduction mechanisms pointed out important commonalities between N/OFQ and classic opioid agonists. Like opioid agonists, N/OFQ inhibits adenylate cyclase and calcium currents and hyperpolarizes neurons by opening potassium channels [20,35].

N/OFQ administration inhibits locomotor activity after intracerebroventricular (i.c.v.) injection of doses of 1-10 nmol $[45,9]$, while it has been reported to increase locomotion at

\footnotetext{
* Corresponding author. Tel.: +39059 2055370; fax: +39 0592055376.

E-mail address: vitale.giovanni@unimore.it (G. Vitale). 
very low doses (0.005-0.05 nmol) [14]. N/OFQ modulates responses to nociceptive stimuli, stimulates feeding behavior, blocks morphine place conditioning and the reinforcing effects of ethanol, interfers with learning and memory functions and alters sensory processing as well [3,5,33].

N/OFQ and NOP receptors are abundantly expressed in limbic and limbic-associated brain structures $[16,15,39,40]$ that are involved in processing of emotionally relevant stimuli, thus raising the hypothesis that N/OFQ might contribute to regulation of the hypothalamic-pituitary-adrenal (HPA) axis, and to regulation of emotional states. Accordingly, i.c.v. injection of N/OFQ or of the NOP receptor agonist Ro 646198 were shown to decrease behavioral responses to stress [18,21-23,50]. PreproN/OFQ knockout mice express high levels of anxiety-related behavior in neophobic tests, suggesting that an intact N/OFQ system is necessary for normal anxiety responses [23]. Furthermore, acute stress exposure decreases $\mathrm{N} / \mathrm{OFQ}$ content in forebrain neurons, implicating endogenous $\mathrm{N} / \mathrm{OFQ}$ neurotransmission in physiological stress responses [12]. However, N/OFQ was also reported to elicit anxiogeniclike responses, to increase plasma concentrations of adrenocorticotropic hormone (ACTH) and corticosterone (CORT) in unstressed rats and to augment hormonal responses in mildly stressed rats [11].

Thus, the literature on this subject is not unanimous: there are reports suggesting an anxiolytic-like effect of N/OFQ $[21,18,22,52,7,17]$, but there are also reports suggesting an anxiogenic-like effect for the peptide [13]. N/OFQ is well known to elicit a clear-cut hypolocomotor effect in rats, which undergoes rapid tolerance [9]. Since hypolocomotion may be associated to emotional consequences, particularly in stressful conditions, the present study was designed to investigate the effect of N/OFQ both following acute and repeated administration of the peptide with the aim of minimizing its effect on locomotion.

Two different behavioral tests were used: the elevated plus maze and the conditioned defensive burying in rats, which measure fear-like responses of a composite nature, generated by exposure to stressful environmental conditions. These classic paradigms were established for their sensitivity to conventional anxiolytic tranquilizers and anxiogenic compounds of various structural classes and mechanisms of action. In particular, the elevated plus maze model is based on rats' innate aversion to open and high places and belongs to the group of unconditioned anxiety paradigms used for the development of putative anxiolytic compounds [25,28]. On the other hand, defensive burying is an innate response exhibited by rats towards aversive stimuli. The defensive burying behavior test has been extensively used to study the neuronal mechanisms underlying anxiety regulation, and was chosen for the present investigation on the basis of its sensitivity to manifest both physiological and pharmacological changes in anxiety [49]. The tests had been previously validated, in our experimental conditions, with prototypical anxiolytic compounds (i.e. diazepam) and had been controlled for effects on sensorimotor function (data not shown). Serum corticosterone (CORT) levels were also evaluated in rats during exposure to the anxiety test after either a single or a double N/OFQ treatment. Moreover, the NOP receptor antagonist UFP-101 was tested in the double N/OFQ administration experiments where a rapid development of tolerance to hypolocomotion can occur. Indeed, data obtained in "in vitro" and in "in vivo" tests have demonstrated that UFP-101 behaves as a potent, competitive and selective antagonist at NOP receptors (for a review, see Calò et al. [4]).

The present study sought to shed new light on the contrasting evidences regarding the N/OFQ effects on anxiety-related behaviors; for this purpose we operated in conditions devoid of locomotor impairment, we utilized differential anxiety tests and also examined how the blockade of N/OFQ-NOP signaling can affect this complex emotional behavior.

\section{Materials and methods}

\subsection{Animals}

Two hundred male Wistar rats weighing 180-200 g, at the beginning of the experiments, were housed in Plexiglas ${ }^{\mathbb{R}}$ cages in groups of three to four in controlled conditions (free access to food and water; 12-h light:12-h dark cycle; temperature, $22 \pm 1{ }^{\circ} \mathrm{C}$; humidity, $60 \%$ ). All testing sessions were performed between 09:00 and 14:00 h. Ethical guidelines for investigation of experimental pain in conscious animals were followed, and procedures were carried out according to EEC ethical regulations for animal research (EEC Council 86/609; D.Lgs. 27/01/ 1992, no. 116).

\subsection{Surgery}

The rats were randomly divided into groups of 10 animals each. For i.c.v. injections, stainless-steel guide cannulae (23 ga) (Plastic One, Roanoke, VA, USA) were stereotaxically implanted in the right lateral ventricle, to a depth of $0.5 \mathrm{~mm}$ above the ventricle (in $\mathrm{mm}$ from the bregma: $\mathrm{AP}=-0.8 ; \mathrm{L}=1.4$; $\mathrm{V}=3.25$ ) [41], under ketamine plus xylazine anesthesia $(115+2 \mathrm{mg} / \mathrm{kg}$ i.p.; Farmaceutici Gellini, Aprilia, Italy and Bayer, Milan, Italy, respectively) and fixed in place with acrylic dental cement and one skull screw. A removable plug was kept in place except during the drug injections. All i.c.v. injections were in a volume of $5 \mu$ l. After the end of the experiment, rats were i.c.v. injected with $5 \mu$ l of dye (Evans Blue) and sacrificed under anesthesia. The correct placement of the cannula was ascertained by inspection of dye diffusion in the right lateral ventricle.

\subsection{Experimental procedure}

In the first set of experiments N/OFQ 0.3, 0.5, 0.75, 1 and $1.5 \mathrm{nmol} / \mathrm{rat}$, or saline was i.c.v. injected in a single administration by means of an injector $(1 \mathrm{~mm}$ longer than the guide cannula) and the animals ( $n=10$ per group) were subjected either to the elevated plus maze test or to the conditioned defensive burying test $5 \mathrm{~min}$ later (amount of rats in experiment $1=120$ ). The rats belonging to the groups submitted to the plus maze test were decapitated 20 min after the end of the test, their blood collected from the trunk, centrifuged at $1000 \times \mathrm{g}$ for $10 \mathrm{~min}$ and serum was removed and stored at $-80^{\circ} \mathrm{C}$ until analysis for corticosterone content 
using enzyme immunoassay (see below). Taking into account the circadian rhythm of corticosterone, all blood samples were taken between 12.00 and 14.00 , i.e. during the diurnal period when its concentrations are relatively constant [1] in order to minimize its fluctuations.

In the second set of experiments the animals were pretreated with the dose of $1 \mathrm{nmol} / \mathrm{rat}$ of N/OFQ (or saline, same volume) $2 \mathrm{~h}$ before the subsequent treatment which consisted in the administration of UFP-101 (10 nmol/rat), or saline, $5 \mathrm{~min}$ before N/OFQ ( $1 \mathrm{nmol} / \mathrm{rat}$ ), or saline (amount of rats in experiment $2=80$ ). The animals were then submitted to the same experimental procedure as previously described.

\subsection{Elevated plus maze test}

The elevated plus maze consisted of two open arms and two enclosed arms each measuring $55 \mathrm{~cm} \times 10 \mathrm{~cm}$, with black wooden floors, emanating from a common central platform $(10 \mathrm{~cm} \times 10 \mathrm{~cm})$ to form a plus shape. The open arms were bounded by $1 \mathrm{~cm}$ high ledges on the sides, but there were no ledges at the ends of the arms. The closed arms had $40 \mathrm{~cm}$ high transparent Plexiglas walls. The maze was elevated $80 \mathrm{~cm}$ above the ground. The rats were brought to the room in a clear plastic neutral box measuring $32 \mathrm{~cm} \times 22 \mathrm{~cm} \times 11 \mathrm{~cm}$.

From the fifth day after surgery, each animal was treated with saline or NOP agonist and/or antagonist and submitted to the elevated plus maze test. The animal was placed in the centre of the maze (central platform = arena) facing an open arm and its behavior recorded by an expert group of experimenters, unaware of the treatments, for a period of $5 \mathrm{~min}$. At the end of each test, the animal was removed and the maze floor was thoroughly cleaned.

Several measures of anxiety-related parameters, as well as motor activity, were obtained through the recording. For each 5 min block, the amount of time that the animal spent engaged in locomotor activity in each portion of the maze was recorded.

Behavioral determinations in the elevated plus maze included the number of open or closed arm entries (defined as the movements of all four paws from one arm to another) and the time spent in open, closed arms and in the central platform [43].

\subsection{Conditioned defensive burying test}

A rectangular Plexiglas burying apparatus consisting of an acryilic cage ( $27 \mathrm{~cm}$ wide $\times 38 \mathrm{~cm}$ long and $38 \mathrm{~cm}$ high), with the floor covered with fine sawdust, was used. A continuously electrified probe consisting of wires wrapped around a wooden dowel was positioned in the apparatus so that it protruded $10.3 \mathrm{~cm}$ into the chamber and was $7.5 \mathrm{~cm}$ from the bottom of the chamber. Contact with the probe produced a shock of $1 \mathrm{~mA}$. Bedding in the chamber was approximatively $5.0 \mathrm{~cm}$ in depth. Animals were habituated (three to four cagemates together) to the apparatus, in the absence of the shock probe, for 15 min each day for 4 consecutive days.

On fifth day, rats were tested individually for $15 \mathrm{~min}$ with the electrified probe in place. The height of bedding behind the probe was measured before testing and at the end of each 30 min test period and was expressed as the height of bedding above the $5.0 \mathrm{~cm}$ of bedding already placed in the chamber.
Fresh bedding was placed in the apparatus before testing each animal. Behavior during the $30 \mathrm{~min}$ test period was recorded and later scored by two independent observers unaware of the treatments. Behaviors measured were: latency to first contact with the probe and to be shocked, latency to initiate burying (defined as pushing bedding material with the snout of forelimbs forward in the direction of the prod) from first contact, total number of shocks received, height of buried bedding and duration of burying behavior over the entire test period [44]. In particular, the latency intended as the time elapsing from the first shock to the display of the burying behavior inversely reflects the animal's reactivity while the cumulative time of burying behavior has been suggested to reflect the rats' anxiety levels in a specific manner $[48,6]$.

\subsection{Serum corticosterone assay}

Assessment of serum corticosterone was done by means of an enzyme immunoassay (EIA) using a commercially available kit (Assay Design Inc., Ann Arbor, MI, USA) which utilizes a microplate reader set at $405 \mathrm{~nm}$. Serum samples were diluted 1:20 in the appropriate assay buffer in order to be within the calibration curve range. The detection limit of the assay was $26.99 \mathrm{pg} / \mathrm{ml}$; intraassay and interassay coefficients of variations were, respectively, 7.8 and $9.8 \%$.

\subsection{Drugs}

The heptadecapeptide N/OFQ (Phe-Gly²-Phe-Thr-Gly-Ala-ArgLys-Ser-Ala-Arg-Lys-Leu-Ala-Asn-Gln) was purchased from Bakem, Merseyside, UK; [Nphe ${ }^{1}$ Arg $^{14}$, Lys $^{15}$-N/OFQ-NH 2 (UFP101) was kindly supplied by Drs. R. Guerrini and G. Calò (University of Ferrara).

\subsection{Statistical analysis}

All values are expressed as mean \pm S.E.M. A one-way ANOVA followed by Bonferroni test was used to analyze the effects of a treatment with increasing doses of N/OFQ in the elevated plus maze or in the conditioned defensive burying tests as well as on corticosterone levels. A two-way ANOVA was used to analyze the effects of UFP-101 pretreatment, N/OFQ treatment and their interaction. The Bonferroni post hoc test was used for the twoway ANOVA when the effects of UFP-101 and N/OFQ were separately evaluated. The level of significance was set at 0.05 .

\section{Results}

\subsection{Anxiety tests following single injection}

In our first set of experiments, rats were treated with a single i.c.v. administration of N/OFQ at doses ranging from 0.3 to $1.5 \mathrm{nmol} / \mathrm{rat}$.

At the doses of 0.3 and $0.5 \mathrm{nmol} / \mathrm{rat}, \mathrm{N} / \mathrm{OFQ}$ induced no changes in the elevated plus maze and all values were no different from those of the control group. The higher doses $(0.75,1$ and $1.5 \mathrm{nmol} / \mathrm{rat})$ induced a significant decrease in the time spent in the open arms [ANOVA: $F(5,54)=33.26, P<0.01$ ] together with an increase in the time spent in the closed arms 
Table 1 - Effect of the single administration with increasing doses of nociceptin/orphanin FQ (N/OFQ, 0.3-1.5 nmol/rat) in the elevated plus maze test in the rat

\begin{tabular}{|c|c|c|c|c|c|c|c|}
\hline Treatment & $\begin{array}{c}\text { Time spent } \\
\text { in the open } \\
\text { arms (s) }\end{array}$ & $\begin{array}{c}\text { Time spent } \\
\text { in the closed } \\
\text { arms (s) }\end{array}$ & $\begin{array}{c}\text { Time spent } \\
\text { in the central } \\
\text { platform (s) }\end{array}$ & $\begin{array}{c}\text { Open arm } \\
\text { entry } \\
\text { counts }\end{array}$ & $\begin{array}{c}\text { Closed arms } \\
\text { entry } \\
\text { counts }\end{array}$ & $\begin{array}{l}\text { Motor activity } \\
\text { in the open } \\
\text { arms (s) }\end{array}$ & $\begin{array}{c}\text { Motor activity } \\
\text { in the closed } \\
\text { arms (s) }\end{array}$ \\
\hline Saline & $85.4 \pm 10.6$ & $171.8 \pm 9.9$ & $42.7 \pm 4.3$ & $3.23 \pm 0.45$ & $6.01 \pm 0.63$ & $24.12 \pm 3.13$ & $46.28 \pm 5.10$ \\
\hline N/OFQ $0.3 \mathrm{nmol}$ & $78.8 \pm 9.7$ & $181.2 \pm 10.7$ & $40.1 \pm 4.2$ & $3.13 \pm 0.56$ & $5.63 \pm 0.61$ & $22.17 \pm 497$ & $39.78 \pm 5.97$ \\
\hline N/OFQ $0.5 \mathrm{nmol}$ & $75.0 \pm 7.9$ & $184.2 \pm 11.1$ & $41.1 \pm 4.7$ & $3.21 \pm 0.65$ & $4.89 \pm 0.52$ & $24.53 \pm 6.41$ & $43.26 \pm 4.88$ \\
\hline N/OFQ $0.75 \mathrm{nmol}$ & $8.9 \pm 4.6^{*}$ & $218.6 \pm 9.7^{*}$ & $72.5 \pm 6.9^{*}$ & $2.87 \pm 0.81$ & $2.57 \pm 0.78^{*}$ & $4.91 \pm 2.01^{*}$ & $16.51 \pm 6.01^{*}$ \\
\hline N/OFQ $1.0 \mathrm{nmol}$ & $4.9 \pm 1.8^{*}$ & $221.7 \pm 9.4^{*}$ & $73.4 \pm 6.8^{*}$ & $2.07 \pm 0.76$ & $1.61 \pm 0.70^{*}$ & $3.12 \pm 1.97^{*}$ & $7.17 \pm 3.84^{*}$ \\
\hline $\mathrm{N} / \mathrm{OFQ}, 1.5 \mathrm{nmol}$ & $0.9 \pm 1.0^{*}$ & $224.3 \pm 10.1^{*}$ & $75.1 \pm 7.0^{*}$ & $2.23 \pm 0.79$ & $1.29 \pm 0.94^{*}$ & $0.48 \pm 0.40^{*}$ & $6.51 \pm 3.44^{*}$ \\
\hline
\end{tabular}

N/OFQ or saline were i.c.v. administered 5 min before the elevated plus maze test. Values ere expressed as mean \pm S.E.M. for 10 rats for each group.

$P<0.05$ vs. saline (one-way ANOVA followed by Bonferroni test).

$[F(5,54)=5.63, P<0.01]$ and in the central arena $[F(5,54)=9.36$, $P<0.01]$. These effects appear to proceed in a dose-dependent manner and may be interpreted as an anxiogenic-like pattern of response. However, other changes were associated to the previous ones: a significant decrease in locomotion in both arms $[F(5,54)=9.47, P<0.01$ for open arms; $F(5,54)=13.94$, $P<0.01$ for closed arms] and in the number of entries in the closed arms $[F(5,54)=8.71, P<0.01]$ (Table 1$)$.

In the conditioned defensive burying test, neither the latency to first shock nor the burying behavior latency was modified by N/OFQ at any dose used (Table 2). Furthermore, there was no significant difference in the number of times rats received shocks from contacting the probe. Conversely, N/OFQ induced a reduction of the cumulative burying behavior associated with a decrease in the height of buried bedding, both of which were statistically significant [ANOVA: $F(5,54)=11.13, P<0.01$ and $F(5,54)=17.24, P<0.01$, respectively], beginning from the dose of $0.75 \mathrm{nmol} / \mathrm{rat}$.

\subsection{Anxiety tests following repeated injection}

A second set of experiments was performed pretreating the animals with the same dose of N/OFQ ( $1 \mathrm{nmol} / \mathrm{rat}) 2 \mathrm{~h}$ before treatment. In the plus maze test, the double treatment completely abolished the hypolocomotor effect induced by the single injection of N/OFQ and induced a significant increase in the number of the open arm entries [ANOVA: $F(3,36)=11.89, \quad P<0.01]$ and in the time spent there $[F(3,36)=8.45, P<0.01]$, associated with a reduction in the time spent in the closed arms $[F(3,36)=4.95, P<0.01]$. An increase in locomotor activity in the open arms was recorded too $[F(3,36)=23.62, P<0.01]$. In this second experiment $N / O F Q$ did not show any reduced effect on total locomotor activity and revealed an anxiolytic-like action regarding the above mentioned parameters. The treatment with UFP-101, administered alone at the dose of $10 \mathrm{nmol} / \mathrm{rat}$, induced no significant change in the behavioral parameters in this test but it completely abolished the effect of N/OFQ (1 nmol/rat), bringing back all the parameters to control values (Table 3 ).

In the defensive burying test, the repeated administration of N/OFQ ( $1 \mathrm{nmol} / \mathrm{rat}$ ) failed to induce significant changes in the burying latency, in the number of shocks received and in the latency to first shock. On the other hand, a decrease in height [ANOVA: $F(3,36)=10.59, P<0.01]$ and duration $[F(3,36)=15.48$, $P<0.01$ ] of burying was assessed in comparison with control rats, indicating an anxiolytic-like action not significantly different from that evoked by a single N/OFQ administration in this test. UFP-101 (10 nmol/rat) did not induce any significant change per se in respect to controls even though a tendency to increase test parameters was observed. The pretreatment with UFP-101 significantly prevented the anxiolytic-like effects of $1 \mathrm{nmol} / \mathrm{rat} \mathrm{N} / \mathrm{OFQ}$ on the height of buried bedding and the total duration of burying behavior (Table 4).

Finally, the behavioral results obtained form the control group pretreated with saline $2 \mathrm{~h}$ before the subsequent treatment (experiment 2) were not statistically different from those induced by the singly saline-treated rats (experiment 1) in either test (data not shown).

Table 2 - Effect of the single administration with increasing doses of nociceptin/orphanin FQ (N/OFQ, 0.3-1.5 nmol/rat) in the conditioned defensive burying test in the rat

\begin{tabular}{|c|c|c|c|c|c|}
\hline Treatment & $\begin{array}{l}\text { Latency to first } \\
\text { shock (s) }\end{array}$ & $\begin{array}{l}\text { Latency to bury following } \\
\text { the shock (s) }\end{array}$ & $\begin{array}{l}\text { Received electric } \\
\text { shock counts }\end{array}$ & $\begin{array}{l}\text { Height of buried } \\
\text { bedding }(\mathrm{cm})\end{array}$ & $\begin{array}{l}\text { Duration of } \\
\text { burying (s) }\end{array}$ \\
\hline Saline & $28.8 \pm 3.5$ & $173.4 \pm 18.8$ & $3.4 \pm 0.51$ & $5.2 \pm 0.48$ & $109.3 \pm 10.7$ \\
\hline N/OFQ $0.3 \mathrm{nmol}$ & $34.6 \pm 5.1$ & $218.4 \pm 20.3$ & $4.5 \pm 0.56$ & $4.9 \pm 0.52$ & $95.9 \pm 15.9$ \\
\hline N/OFQ $0.5 \mathrm{nmol}$ & $38.4 \pm 6.2$ & $249.2 \pm 21.6$ & $5.5 \pm 0.94$ & $4.5 \pm 0.62$ & $71.6 \pm 9.3$ \\
\hline $\mathrm{N} / \mathrm{OFQ}, 0.75 \mathrm{nmol}$ & $30.9 \pm 3.8$ & $231.2 \pm 20.5$ & $3.7 \pm 0.87$ & $1.9 \pm 0.40^{\circ}$ & $43.6 \pm 8.4^{*}$ \\
\hline $\mathrm{N} / \mathrm{OFQ} 1.0 \mathrm{nmol}$ & $24.6 \pm 7.2$ & $261.4 \pm 20.9$ & $4.4 \pm 0.63$ & $1.0 \pm 0.51^{*}$ & $34.7 \pm 6.1^{*}$ \\
\hline N/OFQ $1.5 \mathrm{nmol}$ & $33.7 \pm 5.7$ & $217.2 \pm 19.9$ & $5.3 \pm 0.77$ & $0.6 \pm 0.45^{*}$ & $27.9 \pm 7.3^{*}$ \\
\hline
\end{tabular}


Table 3 - Effect of the double administration with nociceptin/orphanin (N/OFQ, 1 nmol/rat, i.c.v.) in the elevated plus maze test in the rat; influence of the pretreatment with the NOP receptor antagonist, UFP-101 (10 nmol/rat, i.c.v.), thereon

\begin{tabular}{|c|c|c|c|c|c|c|c|}
\hline Treatment & $\begin{array}{c}\text { Time spent } \\
\text { in the } \\
\text { open arms (s) }\end{array}$ & $\begin{array}{l}\text { Time spent } \\
\text { in the } \\
\text { closed } \\
\text { arms (s) }\end{array}$ & $\begin{array}{l}\text { Time spent } \\
\text { in the } \\
\text { central } \\
\text { platform (s) }\end{array}$ & $\begin{array}{l}\text { Open } \\
\text { arm } \\
\text { entry } \\
\text { counts }\end{array}$ & $\begin{array}{l}\text { Closed } \\
\text { arms } \\
\text { entry } \\
\text { counts }\end{array}$ & $\begin{array}{l}\text { Motor } \\
\text { activity in } \\
\text { the open } \\
\text { arms (s) }\end{array}$ & $\begin{array}{l}\text { Motor } \\
\text { activity in } \\
\text { the closed } \\
\text { arms (s) }\end{array}$ \\
\hline Saline + saline & $77.7 \pm 8.9$ & $182.5 \pm 16.4$ & $39.8 \pm 6.4$ & $3.48 \pm 0.59$ & $5.94 \pm 0.88$ & $20.31 \pm 3.14$ & $36.99 \pm 4.18$ \\
\hline Saline + N/OFQ $1.0 \mathrm{nmol}$ & $136.2 \pm 13.7^{*}$ & $115.2 \pm 9.8^{*}$ & $48.6 \pm 5.7$ & $9.97 \pm 1.73^{*}$ & $5.32 \pm 0.62$ & $58.76 \pm 5.99^{*}$ & $29.35 \pm 4.01$ \\
\hline UFP-101 $10 \mathrm{nmol}+$ saline & $83.4 \pm 9.6$ & $174.3 \pm 14.6$ & $42.3 \pm 6.1$ & $2.74 \pm 0.61$ & $6.09 \pm 0.79$ & $27.52 \pm 2.41$ & $31.10 \pm 2.99$ \\
\hline $\begin{array}{l}\text { UFP-101 } 10 \mathrm{nmol}+\mathrm{N} / \mathrm{OFQ} \\
1.0 \mathrm{nmol}\end{array}$ & $71.3 \pm 7.8$ & $178.0 \pm 15.3$ & $50.7 \pm 8.1$ & $3.33 \pm 0.44$ & $4.94 \pm 1.03$ & $21.98 \pm 1.84$ & $27.72 \pm 4.18$ \\
\hline \multicolumn{8}{|c|}{$\begin{array}{l}\text { UFP-101 or saline were injected } 5 \text { min after N/OFQ or saline and the rats were tested } 5 \text { min thereafter in the elevated plus maze. N/OFQ } \\
\text { ( } 1 \text { nmol/rat, i.c.v.) was administered twice, the actual treatment following a pretreatment (same dose) performed } 2 \mathrm{~h} \text { before the beginning of } \\
\text { the experiment. Values are expressed as mean } \pm \text { S.E.M. for } 10 \text { rats for each group. } \\
{ }^{*} P<0.05 \text { vs. saline (two-way ANOVA followed by Bonferroni test). }\end{array}$} \\
\hline
\end{tabular}

\begin{tabular}{|c|c|c|c|c|c|}
\hline Treatment & $\begin{array}{l}\text { Latency to first } \\
\text { shock (s) }\end{array}$ & $\begin{array}{l}\text { Latency to } \\
\text { bury following } \\
\text { the shock (s) }\end{array}$ & $\begin{array}{l}\text { Received electric } \\
\text { shock counts }\end{array}$ & $\begin{array}{l}\text { Height of buried } \\
\text { bedding }(\mathrm{cm})\end{array}$ & $\begin{array}{l}\text { Duration of } \\
\text { burying (s) }\end{array}$ \\
\hline Saline + saline & $35.7 \pm 3.9$ & $162.1 \pm 18.9$ & $3.7 \pm 0.72$ & $5.6 \pm 0.65$ & $98.7 \pm 9.8$ \\
\hline Saline + N/OFQ $1.0 \mathrm{nmol}$ & $32.5 \pm 6.0$ & $138.5 \pm 16.8$ & $5.3 \pm 0.66$ & $1.4 \pm 0.41^{*}$ & $28.9 \pm 7.6^{*}$ \\
\hline UFP-101 $10 \mathrm{nmol}+$ saline & $45.2 \pm 5.4$ & $227.6 \pm 21.0$ & $3.5 \pm 0.91$ & $7.9 \pm 1.30$ & $126.9 \pm 13.3$ \\
\hline UFP-101 $10 \mathrm{nmol}+\mathrm{N} / \mathrm{OFQ} 1.0 \mathrm{nmol}$ & $38.1 \pm 4.4$ & $183.6 \pm 20.7$ & $4.7 \pm 0.77$ & $4.7 \pm 0.68$ & $102.3 \pm 11.2$ \\
\hline
\end{tabular}

UFP-101 or saline were injected 5 min after N/OFQ or saline and the rats were tested 5 min thereafter in the defensive burying test. N/OFQ $(1 \mathrm{nmol} / \mathrm{rat}$, i.c.v) was administered twice, the actual treatment following a pretreatment (same dose) performed $2 \mathrm{~h}$ before the beginning of the experiment. Values are expressed as mean \pm S.E.M. for 10 rats for each group.

$\mathrm{P}<0.05$ vs. saline (two-way ANOVA followed by Bonferroni test)

\subsection{Serum corticosterone levels}

A single N/OFQ administration led to an increase in serum corticosterone contents; however this effect did not proceed in a dose-dependent manner. The lowest effective dose in inducing a significant CORT increase was $0.5 \mathrm{nmol} / \mathrm{rat}$ [ANOVA: $F(7,72)=25.79, P<0.01]$. Surprisingly, the elevation of CORT levels were significantly lowered after the double N/OFQ ( $1 \mathrm{nmol} / \mathrm{rat}$ ) administration (if compared with the single one) to a value non-statistically different from the control (Fig. 1).

\section{Discussion}

The results of the present study show that in the elevated plus maze, a single i.c.v. administration of N/OFQ affected the rat behavior in a similar manner to that of anxiogenic-like agents. However, a state of hypomotility may have interfered with the behavioral responses. Following a N/OFQ pretreatment, no reduction in locomotor activity was observed and the behavioral response in the plus maze test was consistent with an anxiolytic-like effect; indeed, classic anti-anxiety drugs exert similar behavioral effects in rodents [19,43,21].

In the conditioned defensive burying paradigm, burying height and duration were decreased either in rats treated with a single administration of N/OFQ (from the dose of $0.75 \mathrm{nmol} /$ rat) or in rats that received a double treatment with $1 \mathrm{nmol} / \mathrm{rat}$ N/OFQ. Anxiolytic drugs (e.g. diazepam) decrease duration and height of burying thus indicating that these parameters can reflect anxiety-related behavior [44,48,26,27]. Probably, in this test locomotor activity may be less important for the outcome of the assay; thus, a clear-cut anxiolytic-like pattern was

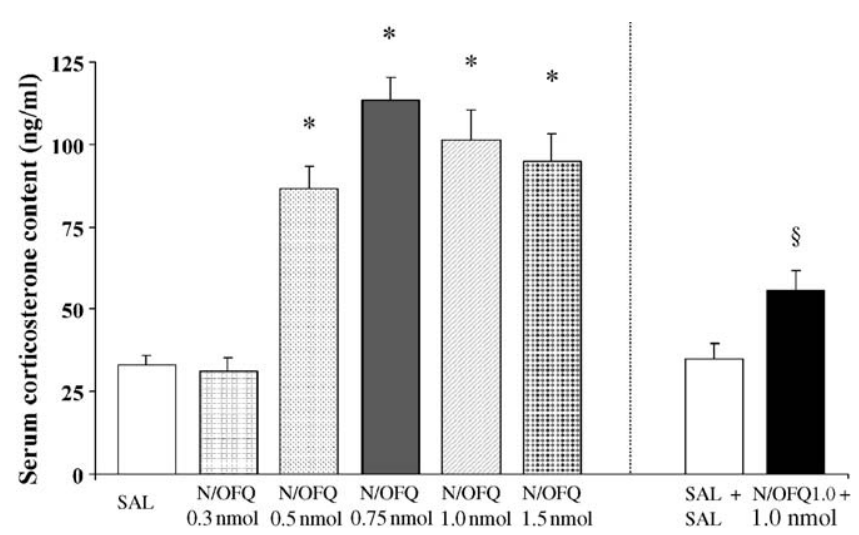

Fig. 1 - N/OFQ or saline (SAL), in single (0.3-1.5 $\mathrm{nmol} / \mathrm{rat})$ or double administration $(1.0+1.0 \mathrm{nmol} /$ rat after $2 \mathrm{~h})$ were i.c.v. administered 5 min before the elevated plus maze test. Twenty minutes thereafter, animals were sacrificed, blood collected and serum obtained and stocked at $-80^{\circ} \mathrm{C}$ for corticosterone (CORT) determination. Values represent the mean \pm S.E.M. for 10 rats for each group. ${ }^{*} P<0.05$ vs. controls and ${ }^{S_{P}}<0.05$ vs. single dose $1.0 \mathrm{nmol} \mathrm{N} / \mathrm{O} / \mathrm{FQ}$ (one-way ANOVA followed by Bonferroni test). 
exhibited either after single or double i.c.v. injection of N/OFQ. Therefore, the similarities of effects produced by either type of N/OFQ treatment in this model further suggest an anxiolytic potential of this drug.

Pretreatment with the potent and selective NOP receptor antagonist UFP-101 (10 nmol/rat) significantly prevented the anxiolytic-like effect of N/OFQ (after double injection) in either anxiety test, indicating that the anxiolytic properties displayed by N/OFQ is mediated by the NOP receptor. Thus, our results demonstrate that the blockade of N/OFQ-NOP signaling is able to affect exogenous N/OFQ-mediated anxiety-related behaviors in rats.

Our findings are in accordance with other reports, in which anxiolytic-like effects of N/OFQ or of the NOP receptor agonist Ro 64-6198, were observed in mice and in rats across several behavioral paradigms generating different types of anxiety states $[21,22,18]$. Our data are also in keeping with the results observed by Koster et al. [23] showing that pre-proN/OFQ knockout mice express high levels of anxiety-related behavior in neophobic tests. The "anxiogenic-like" effect measured in the elevated plus maze after single N/OFQ administration may be explained on the basis of the simultaneous occurrence of a sharp hypolocomotor effect induced by the peptide, effect that undergoes rapid development of tolerance after repeated injections, as indicated by Devine et al. [9].

Fernandez et al. [13] reported that i.c.v. injection of N/OFQ (0.001-1 nmol/rat) increases anxiety-related behavior in rats, using three neophobic tests including the elevated plus maze test; these behavioral findings were associated with increased circulating concentrations of corticosterone. However, it should be emphasized that these results were obtained following acute injection of N/OFQ that is in conditions in which also in our experimental schedule the results of the elevated plus maze were suggestive of an anxiogenic effect. The present study indicates that the effect of N/OFQ in tests of anxiety may be markedly influenced by the emotional consequences of its hypolocomotor effect in stressful conditions; therefore it will be interesting to investigate the effect of repeated injections of N/OFQ also in the other tests used by the group of Fernandez et al. [13].

N/OFQ tolerance to hypolocomotion may depend on desensitization and/or internalization processes of the NOP receptor after repeated administration of the agonist. Spampinato et al. [46,47] reported that N/OFQ can promote internalization of the human NOP (hNOP) receptor in the neuroblastoma cell line SK-N-BE, and that beta-arrestin 2 was involved in this process. An alternative hypothesis also proposed, is that exogenous administration of N/OFQ into the VTA produces an immediate long-lasting desensitization of the NOP receptor [38].

Additional mechanisms indicating the dopaminergic system as a target for N/OFQ in this regard are suggested by the observations that dopamine neurons, probably mesolimbic, are involved in N/OFQ-induced modulation of locomotion and its tolerance $[36,37]$. Finally, biphasic effects, like the inverted U-shape function for N/OFQ effect on locomotion $[45,9,10,36]$ are generally suggestive of the presence of multiple sites of action or of multiple receptor subtypes for the drug; in the case of N/OFQ the existence of different subtypes of NOP receptors has not been elucidated yet. These evidences strongly suggests that N/OFQ may act via distinct mechanisms/pathways to induce the complex behavioral response to stressful events and could also explain the maintenance of its effect on anxiety-related behaviors in the presence of a rapid onset of tolerance to hypolocomotion after double administration.

Furthermore, in our experimental conditions N/OFQ dosedependently increased plasma corticosterone levels following acute administration, in keeping with previous reports showing that N/OFQ activates the HPA axis in unstressed rats and increases hormonal responses in the presence of a mild stressor $[11,12]$. Interestingly, a previous treatment with N/OFQ sharply reduced the effect of the peptide on corticosterone.

Elevations in the circulating concentrations of CORT were reported for both anxiolytic and anxiogenic drugs (i.e. diazepam and FG 7142) following acute administration $[29,42,30,8,2,13]$, and the correlation between emotional (anxiolytic versus anxiogenic) and hormonal effects of these drugs seems to be not clear. Thus, CORT responses and anxiety behaviors can be dissociated, the role of CORT being of lesser importance in the induction of anxiety. The anxiolytic actions of N/OFQ are, therefore, likely to arise from central actions of N/OFQ after i.c.v. administration rather than from some indirect response involving circulating CORT.

\section{Conclusions}

The results of the present study serve to indicate that i.c.v. N/ OFQ treatment produces a clear-cut anxiolytic-like effect only in conditions in which the hypolocomotor effect of the peptide is not observed. The serum CORT levels do not seem to be correlated with the anxiety status in our conditions. Taken together, these findings are an important step to facilitate the elucidation of the role of N/OFQ as a regulator of acute anxiety responses. Finally, they once more contribute to strengthen the hypothesis that N/OFQ neurotransmission may participate in normal processing of emotionally salient and stressful stimuli and disregulation of the N/OFQ-NOP system may be involved in psychiatric disorders associated with an altered activity of the HPA axis and/or pathological anxiety states. Further studies with metabolically stable agonists for the NOP receptor will be required to evaluate their potential anxiolytic activity.

\section{R E F E R E N C E S}

[1] Akana SF, Cascio CS, Du J-Z, Levin N, Dallman MF. Reset of feedback in the adrenocortical system: an apparent shift in sensitivity of adrenocorticotrpin to inhibition of corticosterone in the morning and evening. Endocrinology 1986;119:2325-32.

[2] Bitran D, Shiekh M, Dowd JA, Dugan MM, Renda P. Corticosterone is permissive to the anxiolytic effect that results from the blockade of hippocampal mineralcorticoid receptors. Pharmacol Biochem Behav 1998;60:879-87.

[3] Calò G, Guerrini R, Rizzi A, Salvadori S, Regoli D. Pharmacology of nociceptin and its receptor-a novel therapeutical target. Br J Pharmacol 2000;129:1261-83.

[4] Calò G, Guerrini R, Rizzi A, Salvadori S, Burmeister M, Kapusta DR, et al. PUFP-101, a peptide antagonist selective 
for the nociceptin/orphanin FQ receptor. CNS Drug Rev 2005;11(2):97-112.

[5] Ciccocioppo R, Panocka I, Polidori C, Regoli D, Massi M. Effect of nociceptin on alcohol intake in alcohol-preferring rats. Psychopharmacology 1999;141:220-4.

[6] Craft RM, Howard JL, Pollard GT. Conditioned defensive burying as a model for identifying anxiolytics. Pharmacol Biochem Behav 1988;30(3):775-80.

[7] Dautzenberg FM, Wichmann J, Higelin J, Py-Lang G, Kratzeisen C, Malherbe P, et al. Pharmacological characterization of the novel nonpeptide orphanin $\mathrm{FQ} /$ nociceptin receptor agonist Ro 64-6198: rapid and reversible desensitization of the ORL1 receptor in vitro and lack of tolerance in vivo. J Pharmacol Exp Ther 2001;298(2):812-9.

[8] de Boer SF, Slagen JL, Van der Gugten J. Effects of buspirone and chlordiazepoxide on plasma catecholamine and corticosterone levels in stressed and nonstressed rats. Pharmacol Biochem Behav 1991;38:299-308.

[9] Devine DP, Taylor L, Reinscheid RK, Monsma Jr FJ, Civelli O, Akil $\mathrm{H}$. Rats rapidly develop tolerance to the locomotorinhibiting effects of the novel neuropeptide orphanin FQ. Neurochem Res 1996;21:1387-96.

[10] Devine DP, Taylor L, Reinscheid RK, Monsma Jr FJ, Civelli O, Akil $\mathrm{H}$. The novel peptide orphanin FQ fails to produce conditioned place preference or aversion. Brain Res 1996;727:225-9.

[11] Devine DP, Watson SJ, Akil H. Orphanin FQ regulates neuroendocrine function of the limbic-hypothalamicpituitary-adrenal axis. Neuroscience 2001;102:541-53.

[12] Devine DP, Hoversten MT, Ueda Y, Akil H. Nociceptin/ orphanin FQ content is decreased in forebrain neurons during acute stress. J Neuroendocrinol 2002;15:69-74.

[13] Fernandez F, Misilmeri MA, Felger JC, Devine DP. Nociceptin/orphanin FQ increases anxiety-related behaviour and circulating levels of corticosterone during neophobic tests of anxiety. Neuropsychopharmacology 2004;29(1):59-71.

[14] Florin S, Suaudeau C, Meunier JC, Costentin J. Nociceptin stimulates locomotion and exploratory behaviour in mice. Eur J Pharmacol 1996;317:9-13.

[15] Florin S, Leroux-Nicolett I, Meunier JC, Costentin J. Autoradiographic localization of $\left[{ }^{3} \mathrm{H}\right]$ nociceptin binding sites from telencephalic to mesencephalic regions of the mouse brain. Neurosci Lett 1997;230:33-6.

[16] Foddi MC, Mennini T. $\left[{ }^{125} \mathrm{I}\right]\left[\mathrm{Tyr}^{14}\right]$ orphanin binding to rat brain:evidence for labelling the opioid-receptor-like 1 (ORL1). Neurosci Lett 1997;230:105-8.

[17] Gavioli EC, Rae GA, Calò G, Guerrini R, De Lima TC. Central injections of nocistatin or its C-terminal hexapeptide exert anxiogenic-like effect on behavior of mice in the plus-maze test. Br J Pharmacol 2002;136(5):764-72.

[18] Greibel G, Perrault G, Sanger DJ. Orphanin FQ, a novel neuropeptide with anti-stress-like activity. Brain Res 1999;836:221-4

[19] Handley SL, Mithani JS. Effects of alpha-adrenoceptor agonists and antagonists in a maze-exploration model of 'fear'-motivated behaviour. Naunyn-Schmiedeberg's Arch Pharmacol 1984;327:1-5.

[20] Hawes BE, Graziano MP, Lambert DG. Cellular actions of nociceptin: transduction mechanisms. Peptides 2000;21:961-7.

[21] Jenck F, Moreau J-L, Martin JR, Kilpatrick GJ, Reinscheid RK, Monsma Jr FJ, et al. Orphanin FQ acts as an anxiolytic to attenuate behavioural responses to stress. Proc Natl Acad Sci USA 1997;94:14854-8.

[22] Jenck F, Wichmann J, Dautzenberg FM, Moreau J-L, Ouagazzal AM, Martin JR, et al. A synthetic agonist at the orphanin FQ/nociceptin receptor ORL1: anxiolytic profile in the rat. Proc Natl Acad Sci USA 2000;97:4938-43.
[23] Koster A, Montkowski A, Schulz S, Stube EM, Knaudt K, Jenck F, et al. Targeted disruption of the orphanin FQ/ nociceptin gene increases stress susceptibility and impairs stress adaptation in mice. Proc Natl Acad Sci USA 1999;96:10444-9.

[24] Lachowicz JE, Shen Y, Monsma Jr FG, Sibley DR. Molecular cloning of a novel G protein-coupled receptor related to the opiate receptor family. J Neurochem 1995;64:34-40.

[25] Lister GG. Ethologically based animal models of anxiety disorders. Pharmacol Ther 1990;46(1):321-40.

[26] Lopez-Rubalcava C, Fernandez-Guasti A, Urba-Holmgren R. Age-dependent differences in the rat's conditioned difensive burying behavior: effect of $5-\mathrm{HT}_{1 \mathrm{~A}}$ compounds. Dev Psychobiol 1996;29(2):157-69.

[27] Lopez-Rubalcava C, Cruz SL, Fernandez-Guasti A. Blockade of the anxiolytic-like action of ipsapirone and buspirone, but not that of 8-OH-DPAT, by adrenalectomy in male rats. Psychoneuroendocrinology 1999;24(4):409-22.

[28] Maisonnette S, Morato S, Brandao ML. Role of resocialization and 5-HT1A receptor activation on the anxiogenic effects induced by isolation in the elevated plus-maze test. Physiol Behav 1993;54(4):753-8.

[29] Marc V, Morselli PL. Effect of diazepam on plasma corticosterone levels in the rat. J Pharm Pharmacol 1969;21:784-6.

[30] Matheson GK, Gage D, White G, Dixon V, Gipson D. A comparison of the effects of buspirone and diazepam on plasma corticosterone levels in rat. Neuropharmacology 1988;27:823-30.

[31] Matthes H, Seward EP, Kieffer B, North RA. Functional selectivity of orphanin FQ for its receptor coexpressed with potassium channel subunit in Xenopus laevis oocytes. Mol Pharmacol 1996;50:447-50.

[32] Meunier JC, Mollereau C, Toll L, Suaudeau C, Moisand C, Alvinerie $\mathrm{P}$, et al. Isolation and structure of the endogenous agonist of opioid receptor-like $\mathrm{ORL}_{1}$ receptor. Nature 1995;337:532-5.

[33] Mogil JS, Pasternak GW. The molecular and behavioral pharmacology of the orphanin $\mathrm{FQ} /$ nociceptin peptide and receptor family. Pharmacol Rev 2001;53:381-415.

[34] Mollereau C, Parmentier M, Mailleux P, Butour JL, Moisand C, Chalon P, et al. ORL1 a novel member of the opioid receptor family: cloning, functional expression and localization. FEBS Lett 1994;341:33-8.

[35] Moran TD, Abdulla FA, Smith PA. Cellular neurophysiological actions of nociceptin/orphanin FQ. Peptides 2000;21:969-76.

[36] Murphy NP, Ly HT, Maidment NT. Intracerebroventricular orphanin $\mathrm{FQ} /$ nociceptin suppresses dopamine release in the nucleus accumbens of anaesthetized rats. Neuroscience 1996;75:1-4.

[37] Murphy NP, Maidment NT. Orphanin FQ/nociceptin modulation of mesolimbic dopamine transmission determined by microdialysis. J Neurochem 1999;73:179-86.

[38] Narayanan S, Lufty K, Maidment N. Sensitization to cocaine after a single intra-cerebral injection of orphanin FQ/ nociceptin. Behav Brain Res 2002;131:97-103.

[39] Neal Jr CR, Mansour A, Reinscheid RK, Nothacker HP, Civelli O, Akil H, et al. Opioid receptor-like (ORL1) receptor distribution in the rat central nervous system: comparison of ORL1 receptor mRNA expression with ${ }^{125} \mathrm{I}-[(14) \mathrm{Tyr}]-$ orphanin FQ binding. J Comp Neurol 1999;412:563-605.

[40] Neal Jr CR, Mansour A, Reinscheid RK, Nothacker HP, Civelli O, Watson Jr SJ. Localization of orphanin FQ (nociceptin) peptide and messenger RNA in the central nervous system of the rat. J Comp Neurol 1999;406:503-47.

[41] Paxinos G, Watson C. The rat brain stereotaxic coordinates New York: Academic Press; 1997. 
[42] Pellow S, File SE. The effect of putative anxiogenic compounds (FG 7142, CGS 8216 and Ro 15-1788) on the rat corticosterone response. Physiol Behav 1985;35:587-90.

[43] Pellow S, File SE. Anxiolytic and anxiogenic drug effects on exploratory activity in an elevated plus maze: a novel test of anxiety in the rat. Pharmacol Biochem Behav 1986;24:525-9.

[44] Pinel JPJ, Treit D. Burying as defensive response in rats. J Comp Physiol Psychol 1978;92:708-12.

[45] Reinscheid RK, Nothacker HP, Bourson A, Ardati A, Henningsen RA, Bunzow JR, et al. Orphanin FQ: a neuropeptide that activates an opioid-like G-proteincoupled receptor. Science 1995;270:792-4.

[46] Spampinato S, Di Toro R, Qasem AR. Nociceptin-induced internalization of the ORL1 receptor in human neuroblastoma cells. Neuroreport 2001;12:3159-63.

[47] Spampinato S, Di Toro R, Alessandri M, Murari G. Agonistinduced internalization and desensitization of the human nociceptin receptor expressed in CHO cells. Cell Mol Life Sci 2002;59:2172-83.

[48] Treit D, Pinel JPJ, Fibiger HC. Conditioned defensive burying: a new paradigm for the study of anxiolytic agents. Pharmacol Biochem Behav 1981;15:619-26.
[49] Treit D. Animal models for the study of antianxiety agents: a review. Neurosci Biobehav Rev 1985;9:203-22.

[50] Varty GB, Hyde LA, Hodgson RA, Lu SX, McCool MF, Kazdoba TM. Characterization of the nociceptin receptor (ORL-1) agonist, Ro64-6198, in test of anxiety across multiple species. Psychopharmacology 2005;182:132-43.

[51] Wang JB, Johnson PS, Imai Y, Persico AM, Ozenberger BA, Eppler CM, et al. cDNA cloning of an orphan opiate receptor gene family member and its splice variant. FEBS Lett 1994;348:75-9.

[52] Wichmann J, Adam G, Rover S, Hennig M, Scalone M, Cesura AM, et al. Synthesis of (1S,3aS)-8-(2,3,3a,4,5, 6hexahydro-1H-phenalen-1-yl)-1-phenyl-1,3,8-triazaspiro[4. 5]decan-4-one, a potent and selective orphanin FQ (OFQ) receptor agonist with anxiolytic-like properties. Eur J Med Chem 2000;35:839-51.

[53] Wick MJ, Minnerath SR, Lin X, Elde R, Law PY, Loh $\mathrm{HH}$. Isolation of a novel cDNA encoding a putative membrane receptor with high homology to the cloned $\mu, \delta$ and $\kappa$ opioid receptors. Mol Brain Res 1994;27:37-44. 